\title{
EFFECTS OF POSTURE ON PLASMA VOLUME AND SOME BLOOD CONSTITUENTS
}

\author{
BY \\ J. K. FAWCETT AND V. WYNN \\ From the Surgical Unit, St. Mary's Hospital, London
}

(RECEIVED FOR PUBLICATION MARCH 18, 1960)

\begin{abstract}
When the posture was changed from horizontal to vertical, or the reverse, the alteration in plasma volume and in the levels of haematocrit, haemoglobin, and plasma protein was much greater in patients with oedema or low plasma protein or albumin concentrations (" the pathological group ") than in patients without these abnormalities ("the control group "). This larger fluid shift, and the larger concentration changes dependent on it, are explained in terms of Starling's hypothesis.

In the control group there was scarcely any change in the total mass of intravascular plasma protein with change in posture, but in the pathological group this was often considerable. This was interpreted as indicating increased permeability of the capillaries to protein.

Attention is drawn to the influence of uncontrolled alterations in posture on biochemical and haematological measurements and a recommendation is made in order to standardize conditions before taking blood for the analysis of non-diffusible constituents.
\end{abstract}

It has been known for many years that posture has a great effect on the concentration of certain blood constituents (Böhme, 1911) and on the plasma volume (Thompson, Thompson, and Dailey, 1928), but little account has been taken of such effects in clinical work. The concentration of plasma protein and red cells alters because, on changing from the supine to the erect position, fluid leaves the circulation under the influence of hydrostatic forces and the lower limbs swell (Waterfield, 1931b). In healthy people the plasma volume decreases by about $12 \%$ on changing from lying to standing (Thompson et al., 1928 ; Waterfield, 1931a ; Youmans, Wells, Donley, Miller, and Frank, 1934). This fluid shift is reversed on reverting to the horizontal position.

We became aware of the importance of these changes when investigating the variation during the course of the day of the blood levels of plasma protein and certain other substances (Fawcett and Wynn, 1956b). Early evidence suggested that these effects of posture might be greater in patients with oedema or abnormal plasma protein or albumin concentrations, and it was therefore decided to study the influence of posture in such patients. A control group of subjects, lacking these abnormalities but under similar conditions of admission to hospital, was used for comparison. The effects on the levels of plasma protein, haematocrit, haemoglobin, mean corpuscular色 haemoglobin concentration, total erythrocyte $\stackrel{2}{=}$ volume, and plasma volume are reported and theiro significance discussed.

\section{Subjects and Analytical Methods}

The patients (hereafter designated the pathologicalo group) with oedema or abnormal plasma protein of albumin concentrations are described in Table I. The control group, maintained under similar hospital con-3 ditions, comprised 10 patients awaiting minor surgica $b$ operations or convalescing from them.

Blood samples were taken from a vein of the ante $\frac{D}{9}$ cubital fossa into heparinized syringes, using $0.04 \mathrm{ml}$. of heparin $(5,000$ units per ml.) per $10 \mathrm{ml}$. of blood N When frequent sampling was required, a Guest's cannula was inserted into the vein so as to avoid repeated venepuncture and the necessity for venous ș occlusion. In separate venepunctures, minimum occlusion was used to insert the needle in the vein and the tourniquet was then released for about a? minute before withdrawing blood.

Plasma protein was determined by a semi-micro ${ }^{\text {? }}$ Kjeldahl method (Fawcett, 1954). Albumin and globulin were estimated after precipitation of the

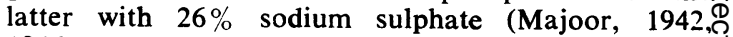

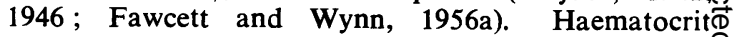
measurements were carried out in triplicate in capped Wintrobe tubes which were centrifuged at 3,000 r.p.m. for 55 minutes in a centrifuge of $15 \mathrm{~cm}$. radius, 8 correcting for trapped plasma according to the data응 
TABLE I

PATHOLOGICAL SUBJECTS

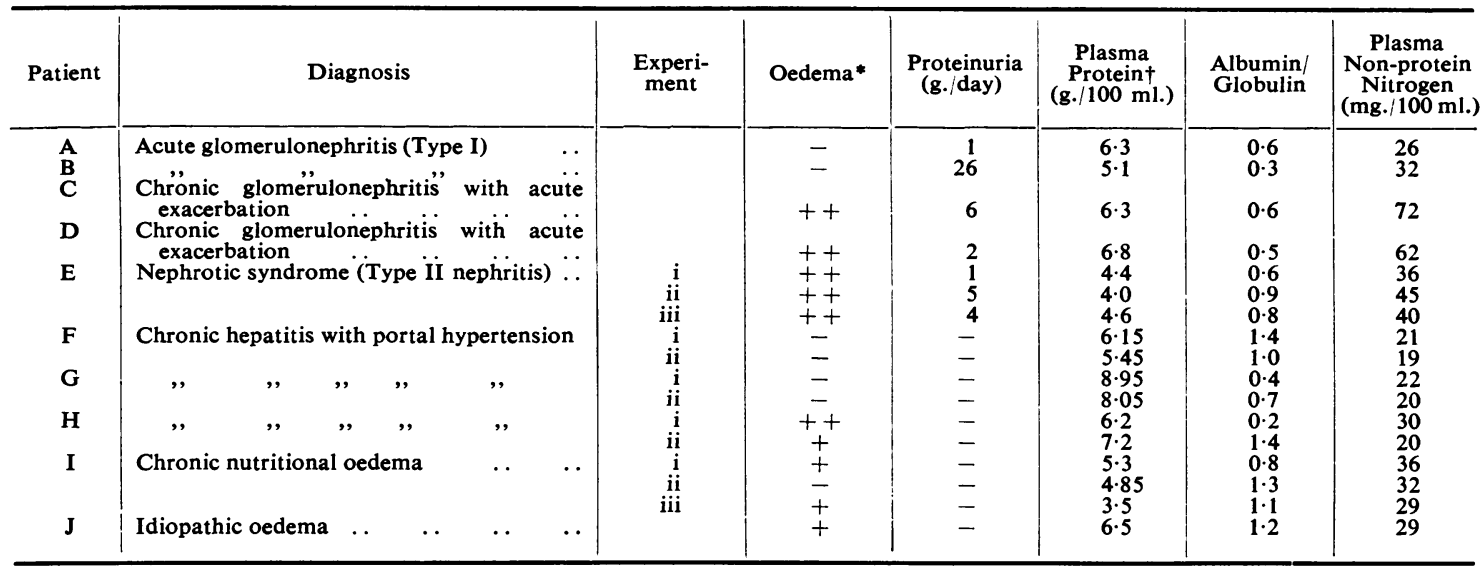

* Pitting of both legs up to the thighs, ++ ; pitting of both legs up to the knees, + . Only case $\mathbf{H}$ had ascites. $\dagger$ Plasma total protein concentration at start of test (horizontal posture)

Sitting, instead of vertical, posture was used in experiments B and Hii.

of Chaplin and Mollison (1952). Blood haemoglobin was determined as oxyhaemoglobin (Bell, Chambers, and Waddell, 1945).

Total circulating erythrocyte volume was measured by labelling some of the subject's own blood cells with $20 \mu \mathrm{c}$. of $\mathrm{Na}_{2}{ }^{51} \mathrm{CrO}_{4}$ (Gray and Sterling, 1950; Mollison and Veall, 1955) and these were reinjected 30 minutes before taking the first blood sample. The erythrocyte volume was then calculated from the concentration of labelled cells in this sample.

Plasma volume was measured with Evans blue dye, using the acetone extraction method of Chinard and Eder (1948), or with human plasma albumin labelled with ${ }^{131} I$. Ten minutes were allowed for equilibration of each tracer material and then at least four samples of plasma were obtained at intervals, the last being obtained between 30 and 60 minutes after the injection. The theoretical concentration at the time of injection was obtained by extrapolation, and the volume of distribution of the tracer was calculated.

\section{Results}

Effects of Posture on Plasma Protein and Haematocrit Levels. - In the standard experimental procedure each subject remained in bed for 12 hours and lay flat for at least one hour. Blood was taken and the subject then assumed the vertical posture for one hour. During this time the subject was slowly walking about, thus ensuring adequate circulation in the lower extremities but avoiding effects due to strenuous exertion. (Youmans et al., 1934, observed that in stationary subjects haemoconcentration in the foot was greater than that in the arm.) Blood was taken 15 minutes and 60 minutes after rising. The subject then resumed the horizontal position, further samples being taken after 15 and 60 minutes. This procedure was used for 10 control subjects and for 12 experiments on nine pathological subjects. Less complete data were obtained in five additional experiments on pathological subjects, and in two of these the patients had to sit in a chair instead of adopting the usual vertical posture.

The percentage changes in protein and haematocrit levels are given in Table II. Fifteen minutes after rising from bed the plasma protein concentration increased by about $10 \%$ in both the control and pathological groups. After an hour there was scarcely any further rise in the controls, but in the pathological subjects the protein level rose higher, averaging $15 \%$ and in several patients about $20 \%$ above the resting values. There was no further increase in plasma protein concentration after one hour. The average decrease 15 minutes after lying down again was about $6 \%$ for the controls and about $9 \%$ for the pathological subjects. After an hour the changes were about $9 \%$ and $13 \%$ respectively. The percentage decreases after returning to bed were less than the corresponding increases because the protein concentration started at higher levels, but the volumes of fluid shift represented were the same.

Similar observations apply to the haematocrit changes, although these were smaller because they reflected alterations in blood volume instead of plasma volume. Fifteen minutes after rising, the haematocrit increased by 7 to $8 \%$ in both groups. After an hour, although there was no further rise 
TABLE II

CHANGES OF PLASMA PROTEIN AND HAEMATOCRIT LEVELS AS PERCENTAGE OF VALUE BEFORE CHANGE OF POSTURE

\begin{tabular}{|c|c|c|c|c|c|c|c|c|c|c|}
\hline \multirow{3}{*}{\multicolumn{2}{|c|}{ Subjects }} & \multirow{3}{*}{$\begin{array}{c}\text { Experi- } \\
\text { ment }\end{array}$} & \multicolumn{4}{|c|}{$\%$ Change in Protein } & \multicolumn{4}{|c|}{$\%$ Change in Haematocrit } \\
\hline & & & \multicolumn{2}{|c|}{ Vertical } & \multicolumn{2}{|c|}{ Horizontal } & \multicolumn{2}{|c|}{ Vertical } & \multicolumn{2}{|c|}{ Horizontal } \\
\hline & & & $15 \mathrm{~min}$ & $60 \mathrm{~min}$. & $15 \mathrm{~min}$ & $60 \mathrm{~min}$. & $15 \mathrm{~min}$ & $60 \mathrm{~min}$. & $15 \mathrm{~min}$ & $60 \mathrm{~min}$. \\
\hline $\begin{array}{r}\text { Control } 1 \\
2 \\
3 \\
4 \\
5 \\
6 \\
7 \\
8 \\
9 \\
10\end{array}$ & $\begin{array}{l}\ldots \\
\ldots \\
\cdots \\
\cdots \\
\cdots \\
\cdots \\
\cdots \\
\cdots\end{array}$ & & $\begin{array}{r}-7.8 \\
+11.4 \\
+6.6 \\
+6.0 \\
+19.0 \\
+10.2 \\
+11.7 \\
+7.6 \\
+10.7\end{array}$ & $\begin{array}{r}+5.0 \\
+9.3 \\
+7.6 \\
+7.6 \\
+10.5 \\
+13.9 \\
+11.8 \\
+13.9 \\
+14.2 \\
+10.7\end{array}$ & $\begin{array}{l}-4 \cdot 9 \\
-2 \cdot 0 \\
-1 \cdot 4 \\
-8 \cdot 2 \\
-9 \cdot 5 \\
-7 \cdot 1 \\
-7 \cdot 7 \\
-8 \cdot 9 \\
-5 \cdot 3 \\
-8 \cdot 4\end{array}$ & $\begin{array}{r}-10.5 \\
-3.4 \\
-5.7 \\
-9.7 \\
-12.9 \\
-11.5 \\
-7.1 \\
-9.7 \\
-10.0 \\
-11.0\end{array}$ & $\begin{array}{r}- \\
+5.7 \\
+6.1 \\
+8.4 \\
+3.6 \\
+11.9 \\
+7.9 \\
+7.1 \\
+6.2 \\
+9.8\end{array}$ & $\begin{array}{r}+2.6 \\
+4.8 \\
+4.5 \\
+8.6 \\
+3.8 \\
+5.4 \\
+9.0 \\
+7.0 \\
+9.8 \\
+10.0\end{array}$ & $\begin{array}{r}-3.4 \\
-2.1 \\
-3.0 \\
-4.8 \\
-5.5 \\
-1.9 \\
-7.2 \\
-6.9 \\
-3.1 \\
-7.5\end{array}$ & $\begin{array}{l}-6.9 \\
-3.6 \\
-7.0 \\
-6.3 \\
-7.5 \\
-5.8 \\
-6.0 \\
-7.2 \\
-9.3 \\
-9.9\end{array}$ \\
\hline \multicolumn{2}{|c|}{$\begin{array}{c}\text { Controls: Mean } \\
\text { S.D. }\end{array}$} & & $\begin{array}{r}+10 \cdot 1 \\
3 \cdot 9\end{array}$ & $\begin{array}{r}+10.5 \\
3.0\end{array}$ & $\begin{array}{r}-6 \cdot 3 \\
3 \cdot 0\end{array}$ & $\begin{array}{r}-9 \cdot 2 \\
2 \cdot 9\end{array}$ & $\begin{array}{r}7 \cdot 4 \\
2 \cdot 4\end{array}$ & $\begin{array}{r}+6.6 \\
2.9\end{array}$ & $\begin{array}{r}-4 \cdot 5 \\
2 \cdot 2\end{array}$ & $\begin{array}{r}-7.0 \\
1.7\end{array}$ \\
\hline $\begin{array}{r}\text { Patient } \\
\text { B } \\
\text { C } \\
\text { D } \\
\text { E }\end{array}$ & $\begin{array}{l}\ldots \\
\ldots \\
\ldots \\
\ldots \\
\ldots \\
\ldots \\
\ldots \\
\ldots\end{array}$ & $\begin{array}{r}\mathrm{i} \\
\mathrm{ii} \\
\mathrm{iii} \\
\mathrm{i} \\
\mathrm{ii} \\
\mathrm{i} \\
\mathrm{ii} \\
\mathrm{i} \\
\mathrm{ii} \\
\mathrm{i} \\
\mathrm{ii} \\
\mathrm{iii}\end{array}$ & $\begin{array}{r}+5.6 \\
+10.3 \\
+9.6 \\
+8.0 \\
+8.9 \\
+\overline{14} \cdot 6 \\
+12.3 \\
+4.5 \\
+11.5 \\
+5.6 \\
+\overline{11} \cdot 3 \\
+8.1 \\
-\end{array}$ & $\begin{array}{r}+10.3 \\
+12.7 \\
+15.9 \\
+12.5 \\
+12.5 \\
+15.0 \\
+18 \cdot 5 \\
+19.8 \\
+18.0 \\
+10.6 \\
+9.9 \\
+11 \cdot 3 \\
+13.2 \\
+17.8 \\
+28.6 \\
+20.1\end{array}$ & $\begin{array}{c}-10.8 \\
-10.3 \\
-7.2 \\
-5.1 \\
-7.6 \\
-7.7 \\
-9.2 \\
-6.6 \\
-13.0 \\
-2.9 \\
-6.7 \\
-7.5 \\
-\end{array}$ & $\begin{array}{r}-13.0 \\
-12.3 \\
-13.0 \\
-13 \cdot 1 \\
-11.1 \\
-19.6 \\
-14.5 \\
-17.1 \\
-11.6 \\
-12.4 \\
-8.0 \\
-8.1 \\
-12.5 \\
-17.0 \\
-16.5\end{array}$ & $\begin{array}{r}+4.7 \\
+\overline{14.8} \\
+7.2 \\
+9.7 \\
+11.8 \\
+9.2 \\
+10.2 \\
+7.7 \\
+9.5 \\
+3.6 \\
+6.1 \\
+5.4 \\
- \\
-\end{array}$ & $\begin{array}{r}+6.9 \\
+10.7 \\
+18.1 \\
+15.0 \\
+11.5 \\
+12.5 \\
+10.7 \\
+14.1 \\
+17.1 \\
+12.5 \\
+8.8 \\
+9.4 \\
+7.1 \\
+12.3 \\
+16.7 \\
+12.2 \\
\end{array}$ & $\begin{array}{c}-8 \cdot 2 \\
-13 \cdot 1 \\
-8 \cdot 4 \\
-4 \cdot 4 \\
-10 \cdot 1 \\
--8 \cdot 3 \\
-12 \cdot 1 \\
-13 \cdot 7 \\
-9 \cdot 4 \\
-2 \cdot 1 \\
-7 \cdot 8 \\
-8 \cdot 4 \\
-\end{array}$ & $\begin{array}{r}-10.5 \\
-9.7 \\
-12.6 \\
-13.5 \\
-9.9 \\
-14.4 \\
-12.3 \\
-17.4 \\
-14.9 \\
-9.4 \\
-8.5 \\
-8.6 \\
-14.1 \\
-16.2 \\
-12.0 \\
-12.0\end{array}$ \\
\hline $\begin{array}{l}\text { Pathological } \\
\text { Mean* } \\
\text { S.D.* }\end{array}$ & \begin{tabular}{c|} 
oup \\
$\ldots$ \\
$\ldots$
\end{tabular} & & $\begin{array}{r}+9 \cdot 2 \\
3 \cdot 0\end{array}$ & $\begin{array}{r}15 \cdot 4 \\
5.0\end{array}$ & $\begin{array}{r}-8 \cdot 6 \\
2 \cdot 8 \\
\end{array}$ & $\begin{array}{r}-13 \cdot 3 \\
3 \cdot 2\end{array}$ & $\begin{array}{r}+8 \cdot 3 \\
3 \cdot 2\end{array}$ & $\begin{array}{r}+12 \cdot 3 \\
3 \cdot 4\end{array}$ & $\begin{array}{r}-8 \cdot 8 \\
3 \cdot 3\end{array}$ & $\begin{array}{r}-12 \cdot 3 \\
2 \cdot 7\end{array}$ \\
\hline $\begin{array}{r}\text { Significance } \\
\text { between } g\end{array}$ & diff & erence & $0 \cdot 1<\mathrm{p}$ & $\mathrm{p}<0.02$ & $0 \cdot 1<\mathrm{p}$ & $\mathrm{p}<0.01$ & $0 \cdot 1<p$ & $\mathrm{p}<0.01$ & $\mathrm{p}<0.01$ & $\mathrm{p}<0.01$ \\
\hline
\end{tabular}

in the controls, in the pathological subjects the haematocrit rose higher, averaging $12 \%$ and in several patients about $17 \%$ above the resting values. As with the protein changes, there was no further rise after one hour. The average decrease 15 minutes after lying down again was about $5 \%$ for the controls and $9 \%$ for the pathological subjects. After an hour the changes were about $7 \%$ and $12 \%$ respectively.

Effects of Posture on Mean Corpuscular Haemoglobin Concentration.-We have measured haematocrit in preference to haemoglobin because we found this can be done with greater precision. In terms of percentage changes the two move in parallel unless there is an alteration in the mean corpuscular volume which would be reflected in a change in the mean corpuscular haemoglobin concentration. To investigate whether this occurs, studies were carried out on haemoglobin and M.C.H.C. levels in five of the experiments described above, the subjects comprising four controls and one patient with the nephrotic syndrome. The results in Table III show that the mean level of M.C.H.C. was slightly $(0.9 \%)$ greater in the horizontal posture than in the vertical, but the difference was not statistically significant.

Effects of Posture on Total Circulating Erythrocyte Volume.-A radioactive isotope technique was used to investigate the possibility that liberation and subsequent sequestration of $\Omega$

TABLE III

EFFECT OF POSTURE UPON MEAN CORPUSCULAR HAEMOGLOBIN CONCENTRATION (G./100 ML.)

\begin{tabular}{|c|c|c|c|c|}
\hline \multirow{2}{*}{ Subject } & \multirow{2}{*}{ Experiment } & \multicolumn{2}{|c|}{ Posture } & \multirow{2}{*}{$\begin{array}{l}\text { Percentage } \\
\text { Difference }\end{array}$} \\
\hline & & Horizontal & Vertical & \\
\hline 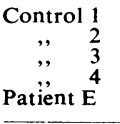 & (i) & $\begin{array}{l}32 \cdot 6 \\
31 \cdot 1 \\
32 \cdot 1 \\
32 \cdot 3 \\
33 \cdot 2\end{array}$ & $\begin{array}{l}32 \cdot 3 \\
30 \cdot 3 \\
32 \cdot 1 \\
32 \cdot 1 \\
33 \cdot 0\end{array}$ & $\begin{array}{l}+0.9 \\
+2.6 \\
0 \\
+0.6 \\
+0.6\end{array}$ \\
\hline $\begin{array}{l}\text { Mean } \\
\text { S.D. } \\
\text { Significance }\end{array}$ & of difference $\mathrm{fr}$ & $\begin{array}{cc}\cdots & \cdots \\
\text { om zero } & \cdots\end{array}$ & $\begin{array}{l}\cdots \\
\cdots \\
\cdots\end{array}$ & $\begin{array}{lc}\ldots & +0.9 \\
\ldots & 1.0 \\
\cdots & 0.1<p\end{array}$ \\
\hline
\end{tabular}


erythrocytes might contribute to the changes in haematocrit. In four experiments (Ei, Fii, Gi, and Ii) on the pathological subjects, in which the rise in haematocrit was an average of $12 \%$, labelled erythrocytes were injected 30 minutes before the start of the experiment. It was found that the activity per unit volume of red cells fell by an average of $0.9 \%$ during the hour after rising. This represented a negligible fraction of the rise in haematocrit and was not significantly different from zero. There was thus no evidence to suggest that sequestered (and therefore unlabelled) erythrocytes were liberated into the circulation on assuming the vertical posture.

It was not possible to investigate in the same way the possibility of erythrocytes being removed from the circulation on lying down, because such sequestered cells would contain the same concentration of radioactivity as those remaining. It would be difficult, however, to postulate that such sequestration occurs on adopting the horizontal posture without the reverse process occurring on standing up.

Effects of Posture on Plasma Volume.-It is difficult to make direct measurements of changes in plasma volume because the methods are not very precise, and when repeated determinations are required in a short period the measurements are complicated and precision further reduced. This is equally true of both the dye and isotope methods. As both tracers are bound to plasma protein, and therefore influenced by its movement from the circulation and changes in its concentration, one cannot dispense with the necessity for two separate injections of the labelling material in order to calculate the response to a change in posture. The second measurement is therefore complicated by the rate of removal of the material first injected. One is thus attempting to assess a relatively small difference between two measurements neither of which can be made with very great precision.

An alternative method of calculating percentage changes in plasma volume (V) can be based on the changes in haematocrit, on the assumption that the total volume (E) of circulating erythrocytes and the ratio of total circulation haematocrit to venous haematocrit are unaffected by posture. This is because

$$
\mathrm{V}=\mathrm{E} \cdot \frac{100-\mathrm{c} . \mathrm{Ht}}{\mathrm{c} . \mathrm{Ht}}
$$

where haematocrit $(\mathrm{Ht})$ is expressed as a percentage, and $c$ is a factor correcting for plasma trapped in the erythrocyte column of the haematocrit tube (Chaplin and Mollison, 1952) and for the difference between total circulation and venous haematocrit (Chaplin, Mollison, and Vetter, 1953).

The validity of this method of calculation depends not only upon the assumption that $E$ is unaffected by posture, which we have confirmed at least within $1 \%$ limits, but also that $c$ is unaffected. Only a considerable redistribution of blood between the large and smaller vessels could have a significant effect on $c$, and this is unlikely to occur.

In an attempt to confirm the validity of using this equation, experiments were carried out on three control and four pathological subjects to measure their changes in plasma volume, after a change in posture, both by direct measurements and by means of equation (1). Six direct measurements were made using Evans blue dye, injecting $15 \mathrm{mg}$. for the first estimation and $30 \mathrm{mg}$. for the second. Human plasma albumin labelled with ${ }^{131}$ I was injected simultaneously with the dye in one of these six subjects and was used instead of the dye in a seventh subject. In two experiments the patients were not well enough to adopt the usual vertical posture for the time necessary to ensure complete adjustment and equilibration of plasma volume (60 minutes) plus that necessary for obtaining samples after the injection (at least 30 minutes). In these patients, the "vertical" posture was represented by sitting in a chair. In all experiments allowance was made for the plasma removed in the blood samples.

Table IV compares the percentage changes in plasma volume obtained by these direct measure-

\section{TABLE IV}

COMPARISON OF CHANGES IN PLASMA VOLUME IN RESPONSE TO CHANGE IN POSTURE CALCULATED BY DIRECT MEASUREMENTS OF PLASMA VOLUME AND FROM EQUATION (1)

\begin{tabular}{|c|c|c|c|c|}
\hline \multirow[b]{2}{*}{ Subjects } & \multirow[b]{2}{*}{ Label } & \multicolumn{3}{|c|}{$\begin{array}{l}\text { Change Calculated as Percentage of } \\
\text { Plasma Volume in Vertical Posture }\end{array}$} \\
\hline & & $\begin{array}{c}\text { Direct } \\
\text { Measure- } \\
\text { ment } \\
\text { (a) }\end{array}$ & $\begin{array}{c}\text { From } \\
\text { Equation (1) } \\
\text { (b) }\end{array}$ & $\begin{array}{l}\text { Difference } \\
\mathbf{a}-\mathbf{b}\end{array}$ \\
\hline $\begin{array}{rr}\text { Control } & \mathbf{1} \\
\text {,, } & \mathbf{2} \\
\text { Patient } & \mathbf{3} \\
\text {,, } & \mathbf{H} \\
\text {,, } & \mathbf{I} \\
\text {,, } & \text { J }\end{array}$ & $\begin{array}{c}\text { Evans blue } \\
\text { Ev1 I }_{\text {I }} \\
\text { Evans blue } \\
\qquad, \\
\text { Ev1 ," } \\
\text { Evans blue } \\
\text {,", }\end{array}$ & $\begin{array}{l}+0.4 \\
+1.5 \\
+9.9 \\
+5.7 \\
+16.9 \\
+14.2 \\
+33.6 \\
+17.0\end{array}$ & $\begin{array}{r}+3.0 \\
+9.3 \\
+5.6 \\
+16.2 \\
+15.4 \\
+28.4 \\
+22.5\end{array}$ & $\begin{array}{l}-2.6 \\
-1.5 \\
+0.6 \\
+0.1 \\
+0.7 \\
-1.2 \\
+5.2 \\
-5.5\end{array}$ \\
\hline $\begin{array}{l}\text { Mean } \\
\text { S.D. } \\
\text { Significanc }\end{array}$ & $\ddot{m} \quad \cdots$ & $\begin{array}{ll}\cdots & \cdots \\
\cdots & \cdots\end{array}$ & $\begin{array}{l}\cdots \\
\cdots\end{array}$ & $\begin{array}{ll}\ldots & -0.5 \\
\cdots & 3.1 \\
\cdots & 0.1<p\end{array}$ \\
\hline
\end{tabular}

${ }^{131} I={ }^{191}$ I-labelled albumin. 
TABLE V

CHANGES OF PlaSma VOLUME AS THE PERCENTAGe VALUE BEFORE POSTURE CHANGE

\begin{tabular}{|c|c|c|c|c|c|}
\hline \multirow{2}{*}{ Subjects } & \multirow{2}{*}{$\begin{array}{c}\text { Experi- } \\
\text { ment }\end{array}$} & \multicolumn{2}{|c|}{ Vertical } & \multicolumn{2}{|c|}{ Horizontal } \\
\hline & & $15 \mathrm{~min}$. & $60 \mathrm{~min}$. & $15 \mathrm{~min}$. & $60 \mathrm{~min}$. \\
\hline $\begin{aligned} & \text { Control 1 } . . \\
& 2 \ldots \\
& 3 . \\
& 4 \cdots \\
& 5 . \\
& 6 . \\
& 7 . \\
& 8 . \\
& 9 . \\
& 10 . \\
&\end{aligned}$ & & $\begin{array}{r}-10 \\
-9 \\
-9 \\
-6 \\
-17 \\
-12 \\
-11 \\
-11 \\
-12\end{array}$ & $\begin{array}{r}-5 \\
-8 \\
-7 \\
-9 \\
-9 \\
-8 \\
-13 \\
-13 \\
-10 \\
-16 \\
-12\end{array}$ & $\begin{array}{r}+6 \\
+4 \\
+5 \\
+9 \\
+10 \\
+3 \\
+14 \\
+12 \\
+6 \\
+11\end{array}$ & $\begin{array}{l}+12 \\
+7 \\
+12 \\
+10 \\
+15 \\
+10 \\
+11 \\
+12 \\
+19 \\
+16\end{array}$ \\
\hline $\begin{array}{l}\text { Controls: Mean } \\
\text { S.D. }\end{array}$ & & $\begin{array}{r}-10.8 \\
3.0\end{array}$ & $\begin{array}{r}-9 \cdot 5 \\
3 \cdot 3\end{array}$ & $\begin{array}{r}+8 \cdot 0 \\
3 \cdot 2\end{array}$ & $\begin{array}{r}+12.5 \\
2.8\end{array}$ \\
\hline 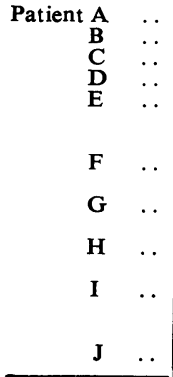 & $\begin{array}{r}\mathrm{i} \\
\mathrm{ii} \\
\mathrm{iii} \\
\mathrm{i} \\
\mathrm{ii} \\
\mathrm{i} \\
\mathrm{ii} \\
\mathrm{i} \\
\mathrm{i} \\
\mathrm{ii} \\
\mathrm{i} \\
\mathrm{ii} \\
\mathrm{iii}\end{array}$ & $\begin{array}{l}-7 \\
-15 \\
-9 \\
-13 \\
-17 \\
-12 \\
-13 \\
-10 \\
-13 \\
-5 \\
-8 \\
-7 \\
=\end{array}$ & $\begin{array}{r}-9 \\
-16 \\
-18 \\
-16 \\
-16 \\
-18 \\
-14 \\
-18 \\
-20 \\
-15 \\
-13 \\
-12 \\
-12 \\
-17 \\
-23 \\
-17\end{array}$ & $\begin{array}{r}+13 \\
+17 \\
+11 \\
+7 \\
+19 \\
+13 \\
+20 \\
+24 \\
+17 \\
+3 \\
+12 \\
+15 \\
+1 \\
=\end{array}$ & $\begin{array}{l}+17 \\
+18 \\
+16 \\
+19 \\
+17 \\
+28 \\
+21 \\
+21 \\
+29 \\
+25 \\
+17 \\
+12 \\
+15 \\
+20 \\
+30 \\
+\overline{22}\end{array}$ \\
\hline 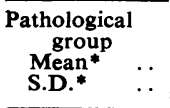 & & $\begin{array}{r}-10.7 \\
3.4 \\
\end{array}$ & $\begin{array}{r}-15.7 \\
3.6\end{array}$ & $\begin{array}{r}+14.2 \\
5.0\end{array}$ & $\begin{array}{r}21.0 \\
5.4 \\
\end{array}$ \\
\hline $\begin{array}{l}\text { Significance of } \\
\text { between grou }\end{array}$ & $\begin{array}{l}\text { lifference } \\
\text { os } . .\end{array}$ & $0 \cdot 1<p$ & $p<0.01$ & $\mathrm{p}<0.01$ & $p<0.01$ \\
\hline
\end{tabular}

* Excluding experiments $\mathrm{B}$ and $\mathrm{Hii}$, in which sitting replaced the vertical posture.

ments and by means of equation (1). There is no evidence of a systematic difference and agreement is generally good in view of the inherent lack of precision of the direct measurements. We regard this as confirmation of the validity of using the equation to assess percentage changes in plasma volume. Changes calculated in this way from the haematocrit data in Table II are reported in Table V.

In the control group the average change on moving from the horizontal to the vertical posture was about $-10 \%$ and the change on resuming the horizontal was about $+12 \%$. In most of the pathological group the plasma volume changes were greater, sometimes reaching $30 \%$.

As with the plasma protein and haematocrit levels, the percentage changes in plasma volume on rising differed from those on returning to bed. This is because of the differences in the starting levels, not because of differences in the volumes of fluid transferred.
Effects of Posture on Total Mass of Intravascular Plasma Protein.-From our values for $\overrightarrow{\overrightarrow{\hat{s}}}$ the percentage changes of plasma volume and protein concentration it is possible to estimate the $\frac{C}{\partial}$ corresponding changes in the total quantity $(P) \overline{\bar{c}}$ of plasma protein within the vascular circulation. $\overparen{\mathbb{D}}$ This is because

$$
\mathbf{P}=\mathrm{V} .[\mathrm{Pr}]
$$

where $[\mathrm{Pr}]$ represents plasma protein concentration and from equations (1) and (2),

$$
\frac{\mathrm{P}}{\mathrm{E}}=[\mathrm{Pr}] \frac{100-\mathrm{c} . \mathrm{Ht}}{\mathrm{c} . \mathrm{Ht}}
$$

If $E$ is constant, percentage changes in $P$ are equal $\vec{\omega}$ to percentage changes in the right-hand side of the equation.

Table VI shows the mean alterations in this $\mathbf{P} / \mathbf{E}$ ratio. In our control group the alterations tended in the same direction as plasma volume $\vec{c}$ but were very small. Therefore we believe that the total mass of intravascular plasma protein in these subjects was scarcely affected by posture,

TABLE VI

CHANGES OF P/E* AS PERCENTAGE OF VALUE BEFORE

\begin{tabular}{|c|c|c|c|c|c|c|}
\hline \multirow{2}{*}{\multicolumn{2}{|c|}{ Subjects }} & \multirow{2}{*}{$\begin{array}{l}\text { Experi- } \\
\text { ment }\end{array}$} & \multicolumn{2}{|c|}{ Vertical } & \multicolumn{2}{|c|}{ Horizontal } \\
\hline & & & $15 \mathrm{~min}$. & $60 \mathrm{~min}$. & $15 \mathrm{~min}$. & $60 \mathrm{~min}$. \\
\hline $\begin{array}{r}\text { Control } 1 \\
2 \\
3 \\
4 \\
5 \\
6 \\
7 \\
8 \\
9 \\
10\end{array}$ & \begin{tabular}{l|}
$\cdots$ \\
$\cdots$ \\
$\cdots$ \\
$\cdots$ \\
$\cdots$ \\
$\cdots$ \\
$\cdots$ \\
$\cdots$
\end{tabular} & & $\begin{array}{r}-3 \\
-3 \\
0 \\
0 \\
0 \\
-1 \\
-3 \\
+1 \\
-4 \\
-3\end{array}$ & $\begin{array}{r}0 \\
0 \\
-1 \\
0 \\
+3 \\
+5 \\
-3 \\
+3 \\
-4 \\
-3\end{array}$ & $\begin{array}{l}+1 \\
+2 \\
+4 \\
-1 \\
0 \\
-4 \\
+4 \\
+2 \\
+1 \\
+2\end{array}$ & $\begin{array}{l}+1 \\
+4 \\
+6 \\
0 \\
0 \\
-3 \\
+3 \\
+1 \\
+5 \\
+3\end{array}$ \\
\hline \multicolumn{2}{|c|}{$\begin{array}{c}\text { Controls: Mean } \\
\text { S.D. }\end{array}$} & & $\begin{array}{r}-1.5 \\
1.8\end{array}$ & $\begin{array}{l}0 \\
2 \cdot 6\end{array}$ & $\begin{array}{r}+1 \cdot 1 \\
2 \cdot 5\end{array}$ & $\begin{array}{r}+2 \cdot 0 \\
2 \cdot 8\end{array}$ \\
\hline $\begin{array}{r}\text { Patient } \mathbf{A} \\
\mathbf{B} \\
\mathbf{C} \\
\mathbf{D} \\
\mathbf{E}\end{array}$ & $\begin{array}{l}\ldots \\
\cdots \\
\cdots \\
\cdots \\
\cdots \\
\ldots \\
\ldots\end{array}$ & $\begin{array}{r}\mathbf{i} \\
\mathrm{ii} \\
\mathrm{iii} \\
\mathbf{i} \\
\mathrm{i} \\
\mathrm{i} \\
\mathrm{i} \\
\mathrm{ii} \\
\mathbf{i} \\
\mathrm{ii} \\
\mathrm{i} \\
\mathrm{i} \\
\mathrm{ii}\end{array}$ & $\begin{array}{l}-2 \\
-6 \\
-6 \\
-1 \\
-9 \\
-2 \\
+2 \\
-2 \\
-4 \\
0 \\
+2 \\
-0 \\
-\end{array}$ & $\begin{array}{l}+1 \\
-5 \\
-4 \\
-5 \\
-6 \\
-6 \\
+2 \\
-2 \\
-6 \\
-7 \\
-4 \\
-2 \\
-3 \\
+3 \\
-2 \\
-2 \\
-1\end{array}$ & $\begin{array}{r}+1 \\
+5 \\
+3 \\
+3 \\
+11 \\
+5 \\
+10 \\
+16 \\
+2 \\
0 \\
+5 \\
+7 \\
-\end{array}$ & $\begin{array}{r}+2 \\
+4 \\
+1 \\
+4 \\
+5 \\
+4 \\
+4 \\
+4 \\
+8 \\
+12 \\
+3 \\
+2 \\
+6 \\
+6 \\
+10 \\
+3\end{array}$ \\
\hline $\begin{array}{c}\text { Pathologica } \\
\text { group } \\
\text { Mean } \dagger \\
\text { S.D. } \dagger\end{array}$ & $\begin{array}{l}1 \\
\ldots \\
\cdots\end{array}$ & & $\begin{array}{r}-2 \cdot 7 \\
3 \cdot 5\end{array}$ & $\begin{array}{r}-2 \cdot 9 \\
3 \cdot 0\end{array}$ & $\begin{array}{r}5 \cdot 7 \\
4 \cdot 6\end{array}$ & $\begin{array}{r}+5 \cdot 0 \\
3 \cdot 1\end{array}$ \\
\hline $\begin{array}{l}\text { Significance } \\
\text { between } g\end{array}$ & of $\mathrm{di}$ & $\begin{array}{l}\text { ffference } \\
\text { s } \quad \cdots\end{array}$ & $0 \cdot 1<p$ & $\mathrm{p}<0.05$ & $\mathrm{p}<0.05$ & $\mathrm{p}<0.05$ \\
\hline
\end{tabular}
POSTURE CHANGE

* $\mathbf{P}=$ total mass of intravascular plasma protein. $E=$ total volume of circulating erythrocytes.

$\dagger$ Excluding experiments $\mathrm{B}$ and $\mathrm{Hii}$, in which sitting replaced the vertical posture. 
TABLE VII

ESTIMATED CHANGES OF ONCOTIC PRESSURE IN TERMS OF G. ALBUMIN PER $100 \mathrm{ML}$.

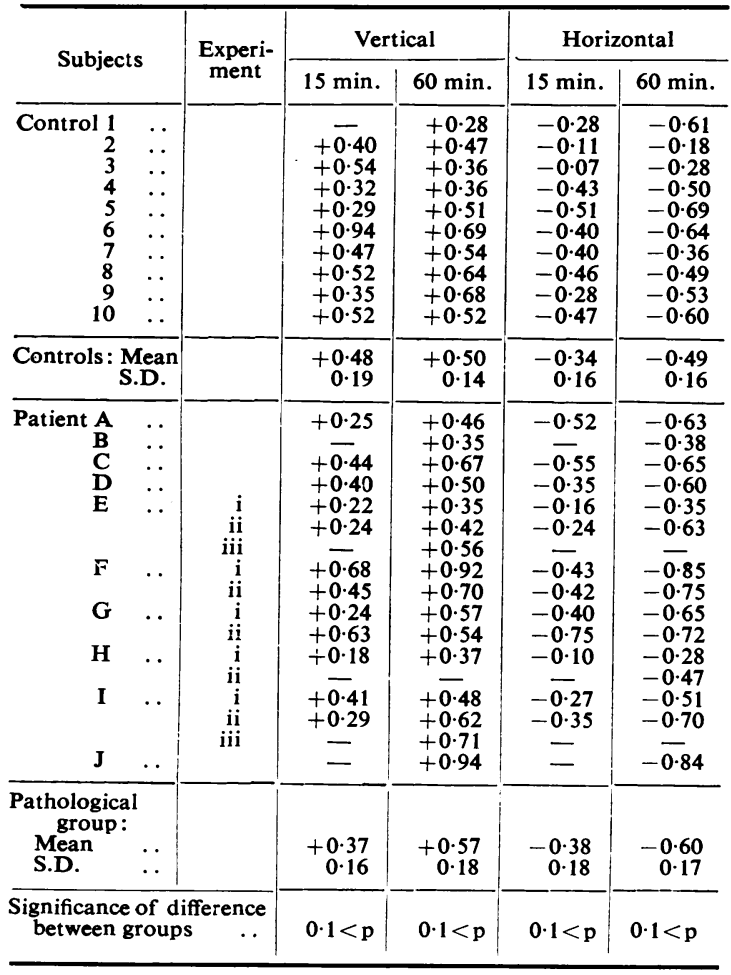

possibly varying by about $1 \%$ of the total intravascular pool. In many of the pathological cases, the $P / E$ ratio varied much more than in the controls, decreasing in the vertical posture and increasing in the horizontal position. In four of the experiments the change in the $P / E$ ratio was between 10 and $16 \%$ of the initial value, representing some 20 to $30 \mathrm{~g}$. of plasma protein. It can be seen from Table VI that the fall in the $P / E$ ratio in the pathological group averaged $2.9 \%$ 60 minutes after rising. On return to the horizontal position $\mathrm{P} / \mathrm{E}$ rose an average of $5.0 \%$ in 60 minutes.

Effects of Posture on Plasma Oncotic Pressure. -We did not attempt to measure plasma oncotic pressure directly, but, for the limited purpose of comparing the changes in our two groups of subjects, we considered it justifiable to calculate on two assumptions: (a) that the oncotic pressure of plasma was entirely dependent on protein concentration, and $(b)$ that globulin, as estimated by our salt-fractionation method, exerted two-fifths of the osmotic effect of an equal mass of albumin. No attempt was made to convert the values into units of pressure: they were expressed as changes in protein concentration, correcting globulin to its albumin equivalent. Thus if an observed change in protein concentration was $1.1 \mathrm{~g}$. per $100 \mathrm{ml}$. and the $A / G$ ratio was $6 / 5$, then the change in plasma oncotic pressure would be represented as $0.6+(2 / 5 \times 0.5)=0.8 \mathrm{~g}$. of albumin per $100 \mathrm{ml}$. Table VII shows that the changes in oncotic pressure, calculated in this way, were similar in the pathological subjects to those in the control series.

\section{Discussion}

These results may be assessed in the light of both their physiological significance and their application to the clinical interpretation of laboratory reports.

The quantitative interpretation of our data, describing the movement of fluid and plasma protein to and from the blood, depends upon the assumption that change of posture is not accompanied by a significant alteration in the volume occupied by the erythrocytes in the circulation or a large alteration in the total circulation: venous haematocrit ratio, or alternatively that any alterations which may occur are similar in health and in disease. We tested this assumption by repeated measurements of M.C.H.C., of the total circulating erythrocyte volume, and of the plasma volume, and we concluded that the haematocrit may be used to calculate changes in plasma volume under the conditions of these experiments, even in disease, and even when the changes were very large. Systematic errors in such calculations were unlikely to exceed about $1 \%$ of the plasma volume.

The changes in plasma protein concentration could not always be used in the same way as the haematocrit because, although large, they were sometimes less than were to be expected from the haematocrit changes. We interpreted this as indicating movement of protein to and from the circulation. For example, in the six instances in which the $\mathrm{P} / \mathrm{E}$ ratio altered within 15 minutes by between 7 and $16 \%$, this would represent the movement of some 15 to $30 \mathrm{~g}$. of plasma protein. The capillary wall is the most probable site at which this quantity of plasma protein could be transferred to and from the circulation in such a short period, and we suggest that increased permeability of the capillaries is therefore indicated in these patients.

According to Starling's hypothesis, the distribution of fluid between capillary blood and the interstitial fluid depends predominantly on the 
hydrostatic pressure within the capillaries being balanced by the plasma oncotic pressure. Our observations are consistent with this because, although the movements of fluid in our pathological cases were larger than in our controls, the changes in plasma oncotic pressure were very similar. In patients with plasma protein abnormalities or increased permeability of the capillaries to protein, larger volume changes are required to bring about the same changes in plasma oncotic pressure, thus balancing the postural changes in hydrostatic pressure. This explains the larger fluid shifts in such subjects.

Because of the large changes in plasma volume which may quickly occur, it is obvious that posture affects the haematocrit, haemoglobin, and other haematological levels, and the concentration of plasma protein, cholesterol, and other relatively non-diffusible constituents, including calcium. As emphasized by Widdowson and McCance (1951), it is important for these effects to be taken into account in clinical work. For example, we have known patients with hypoproteinaemia in whom the diagnosis was not made because they had been walking about before blood was taken for analysis, and in whom the plasma protein levels were much higher than they were subsequently found to be when the patients were confined to bed. Similarly, serial observations on haemoglobin or serum calcium may be invalidated if uncontrolled alter- ations of posture are allowed to influence the results.

We have found that intermediate changes in posture have less effect on the composition of blood than the horizontal-vertical alterations reported in this paper. It is therefore suggested that, in order to standardize the influence of posture, patients should be sitting up in bed or in a chair for at least a quarter of an hour before blood is withdrawn for haematological, plasma protein, or other investigations which might be affected by changes in plasma volume.

We thank Dr. T. Freeman, who kindly supplied the ${ }^{13}{ }^{1}$ I-labelled human plasma albumin, and Mr. K. E. Bicknell and Miss S. M. Slade, who carried out some of the analyses.

\section{REFERENCES}

Bell, G. H., Chambers, J. W., and Waddell, M. B. R. (1945), Biochem. J., 39, 60 .

Böhme, A. (1911). Dtsch. Arch. klin. Med., 103, 522.

Chaplin, H., and Mollison, P. L. (1952). Blood, $7,1227$.

Chi and Vetter, H. (1953). J. clin. Invest., 32, 1309.

Chinard, F. P., and Eder, H. A. (1948). J. exp. Med., 87, 473.

Fawcett, J. K. (1954). J. med. Lab. Technol., 12, 1.

and Wynn, V. (1956a). J. clin. Path., 9, 71 .

(1956b). Brit. med. J., 2, 582.

Gray, S. J., and Sterling, K. (1950). J. Jlin. Invest., $29,1604$.

Majoor, C. L. H. (1942). Thesis. Amsterdam.

(1946). Yale J. biol. Med., 18, 419.

Mollison, P. L., and Veall, N. (1955). Brit. J. Haematol., 1, 62.

Thompson, W. O., Thompson, P. K., and Dailey, M. E. (1928). clin. Invest., 5, 573.

Waterfield, R. L. (1931a). J. Physiol. (Lond.), 72, 110.

W. (1931b). Ibid., 72, 121

Widdowson, E. M., and McCance, R. A. (1951). M.R.C. Spec. Rep. Ser., Wuppertal, 1946-9, No. 275, p. 165. H.M.S.O., Londen. Youmans, J. B., Wells, H. S., Donley, D., Miller, D. G., and Frank, H. (1934). J. clin. Invest., 13, 447. 